\title{
PHYSICAL AND MICROBIOLOGICAL PERFOMANCES OF ACIDIFIED FISH MEAL MADE BY DIPPING INTO EXTRACT SOLUTION OF SAUERKRAUT
}

\author{
B. Sulistiyanto ${ }^{1}$ and K. Nugroho ${ }^{2}$ \\ ${ }^{1}$ Faculty of Animal Agriculture, Diponegoro University, \\ Tembalang Campus, Semarang, Central Java - Indonesia \\ ${ }^{2}$ Kalbe Farma, Surabaya - Indonesia \\ Corresponding E-mail: bsoel05@yahoo.co.id
}

Received October 02, 2009; Accepted November 29, 2009

\begin{abstract}
An experiment was conducted to examine the influence of soaking time into extract solution of Sauerkraut on physic and microbial performances of acidified fish meal. Sauerkraut extract (LPS's sollution) was made by fermentation of wastes vegetable market for 6 days. The LPS-extract was used to acidify " ikan rucah" by the method of dipping for 0,4 and 8 hours. Changes in $\mathrm{pH}$, the total number of bacteria, fungi and proteolytic bacteria, moisture content, odor, colour and texture were parameters observed. Results of experiment showed that total bacteria, fungi and proteolytic bacteria of acidified fish meal significantly influenced by soaking time $(p<0.05)$. No significantly effect was shown to the physically performance. LPS-extract in the soaking effectively reduced content of total bacteria, fungi and proteolytic's bacteria in fish meal.
\end{abstract}

Keywords: performance, fish meal, dipping, Sauerkraut extracts

\section{INTRODUCTION}

Indonesia ocean produces fish as much as \pm 6.4 million tons per year. Total capacity of fishing of all potential resources recommended up to 5.12 million tons per year or $\pm 80 \%$ of the sustainable potency. While the potency is just used for $\pm 40 \%$ (Ilyas et al., 1988) and 10-25\% of the fishing product has been proven out as wastes of fishing (including "ikan rucah").

"Ikan Rucah" has been recognized by a farmer to be a source of protein feed materials, especially for a feed of ducks. However, that fish have been characterized by problem of perishable materials (i.e.: easy to decay). The factors related to those problems are autolysis process, bacteriological process, and rancidity. The conventional method of producing fish meal in farmer scale has been weakened by technology and its quality. Acidified fish meal has advantages in terms of application technology and quality compared to conventional fish meal.

Yunizal (1986) recommended a technology of fish processing by ensiling. Fish silage is a form of hydrolytic protein with other components of the fish in the acid condition, therefore decomposing bacteria can not survive because of $\mathrm{pH}$ 4. The principle of making fish silage is $\mathrm{pH}$ should be low to stop the growth and develop of contaminant decomposing bacteria at the fish (Afrianto and Liviawaty, 2005). Ensiling process of fish is purely biological, process without using chemicals. The method is called fermentation. Fermentation process usually used a number of bacillus species, and the temperature is set to the optimum condition of bacteria (room temperature) at anaerobic atmosphere. Fermentation takes place within 10 days, in which it is marked by the destruction of meat and bone, so that the final form is pasty porridge like and is not stink. Those considered to be the reasons that ensiling method has not well developed.

Acidification is one of techniques preservation of making fish silage. In this term, soaking technique (dipping) is an alternative technique in the preservation. Amin and Leksono (2001) reported that soaking of fish of "Jambal Siam" in solution extract of fermentation of cabbage waste for 3 hours and 60 days of storage prevented the growth of bacteria in the smoked products of "Jambal Siam" fish.

Vegetables market waste is organic waste of traditional markets, usually consists of part of cabbage and Chinese cabbage. As for the local resources, according to the Central Statistics Agency of Semarang Regency-Central Java Province (2005), production of cabbage and Chinese cabbage of Semarang Regency were 
969.06 tons and 789.11 tons per year, respectively. Previous survey noted that the percentage of organic waste of vegetables market reach $5-10 \%$ of gross weight of the vegetables. The previous experiment reported that fermentation of waste vegetable market by adding $2 \%$ of salt and $6.7 \%$ of molasses provide product which is richly organic acid, especially lactic acid and $\mathrm{pH}$ solution reached 3.74 (Sulistiyanto et al., 2009). Utama and Mulyanto (2009) noted that the sauerkraut extract is rich in lactic acid bacterias that had been recommended to be a potential starter of fermentation. Pouwels et al. (1998), Carey et al. (2008) and Christine et al.(2002) reported the capacity of lactic acid bacteria as probiotic production of organic acids, as demonstrated by a decrease in $\mathrm{pH}$ and depressed pathogenic bacteria such as E.coli O157:H7. Rehman et al. (2009) noted the ability of lactic acid bacteria, such as Lactobacillus spp and Bifidobacterium spp in controlling the colonization of enteropathogens in broilers, i.e.: Salmonella spp, Clostridium perfingens and Campylobacter spp.

By dipping mechanism of organic acid, the sauerkraut extract has a highly acidity and contain lactic acid microorganisms. The process of soaking is expected to provide acid atmosphere so that impedes autocatalytic process in the fish meat and prevent activity of decomposing microorganisms. It will produce of acidified fish meal with a good performance.

Based on the reasons above, this experiment was conducted to study the influence of differences time of acidification by using extracts solution of Sauerkraut on physic-organoleptic and microbial performances of acidified fish meal.

\section{MATERIALS AND METHOD}

Extract solution of Sauerkraut was made from Chinese green mustard and cabbage wastes, in which was mixed by $2 \%$ of salt $(w / w)$ and $6.7 \%$ of molasses $(\mathrm{w} / \mathrm{w})$, and incubated for 6 days. Extraction was done mechanically. It was pressed by $10 \mathrm{~kg} / \mathrm{cm} 2$ for 5 minutes, and then extract solution of sauerkraut was used to acidify "Ikan rucah". "Ikan rucah" was taken from "TPITambak Lorok", it was chopped to 3-4 cm, then soaked by extract of Sauerkraut by ratio 1:1 (w/v) with soaking time $0,4,8$ hours. Then, it was drained and dried under the sun. The dried acidified fish was ground passed to 40 mesh. Physical performances (texture, odor, and color), moisture content, total bacteria, fungi and proteolytic bacteria were observed. Data was analyzed by using procedure of GLM-SAS (SASInstitute, 1982).

\section{RESULTS AND DISCUSSION}

Results of research indicated that after 2 days conditioning, the solvent extracts of LPS had $\mathrm{pH} 3.48$, with the fresh sourish smell, so it is feasible to be used as an acidifying reagent. Performance existed after soaking of acidified fish and commercial fish meal is presented in Table 1.

It can be seen that average $\mathrm{pH}$ fish postsoaking 0,4 and 8 hours, followed by incubation were $3.7,3.8$ and 3.8, respectively. The dipping up to 8 hours did not significantly $(p>0.05)$ reduce acidity solution. Moisture content significantly decreased with the time of dipping ( $p$ $<0.05)$. The decline in water level indicates the amount of free water, that was easily evaporated and it was reinforce situation where at the time of fresh the texture became soggy. Exemption of bound water to be free water could indicate as a corruption. Increasing of free water was possibly due to the releasing water from protein by decomposing bacteria or groups of lactic acid bacteria in the Sauerkraut extract's. Commercial fish meal is generally produced by cooking and mechanical extrusion to drip the liquid and any dissolved fats. By this technique, protein had been coagulated during heating, so the amount of disposable free water can be reduced. However, this technique requires further study related to the actual nutritional aspect of treated fish meal and or commercial product.

Content of total bacteria and proteolytic bacteria decreased by time of soaking $(p<0.05)$. Soaking for 4 and 8 hours provided actual total number of bacteria that was lower than in commercial fish meal, those were 4.3 and 3.2 vs. $4.9\left(\times 10^{8} \mathrm{cfu} / \mathrm{g}\right)$. While, the actual proteolytic bacteria was still higher than that in the commercial fish meal, those were 5.6 and 3.2 vs. $0.3\left(\mathrm{x} 10^{8} \mathrm{cfu} / \mathrm{g}\right)$. It could be indicated that most bacteria performed in the fish meal had been dominated by group of lactic acid bacteria. Bacteria used for fermentation of vegetables generally lactic acid type such as Streptococcus, Leuconostoc, Lactobacillus, and Pediococcus. These organisms are capable used sugar to synthesize an organic acid especially lactic acid that may restrict growth of other organisms (Volk and Wheeler, 1992 and Daulay and Rahman 


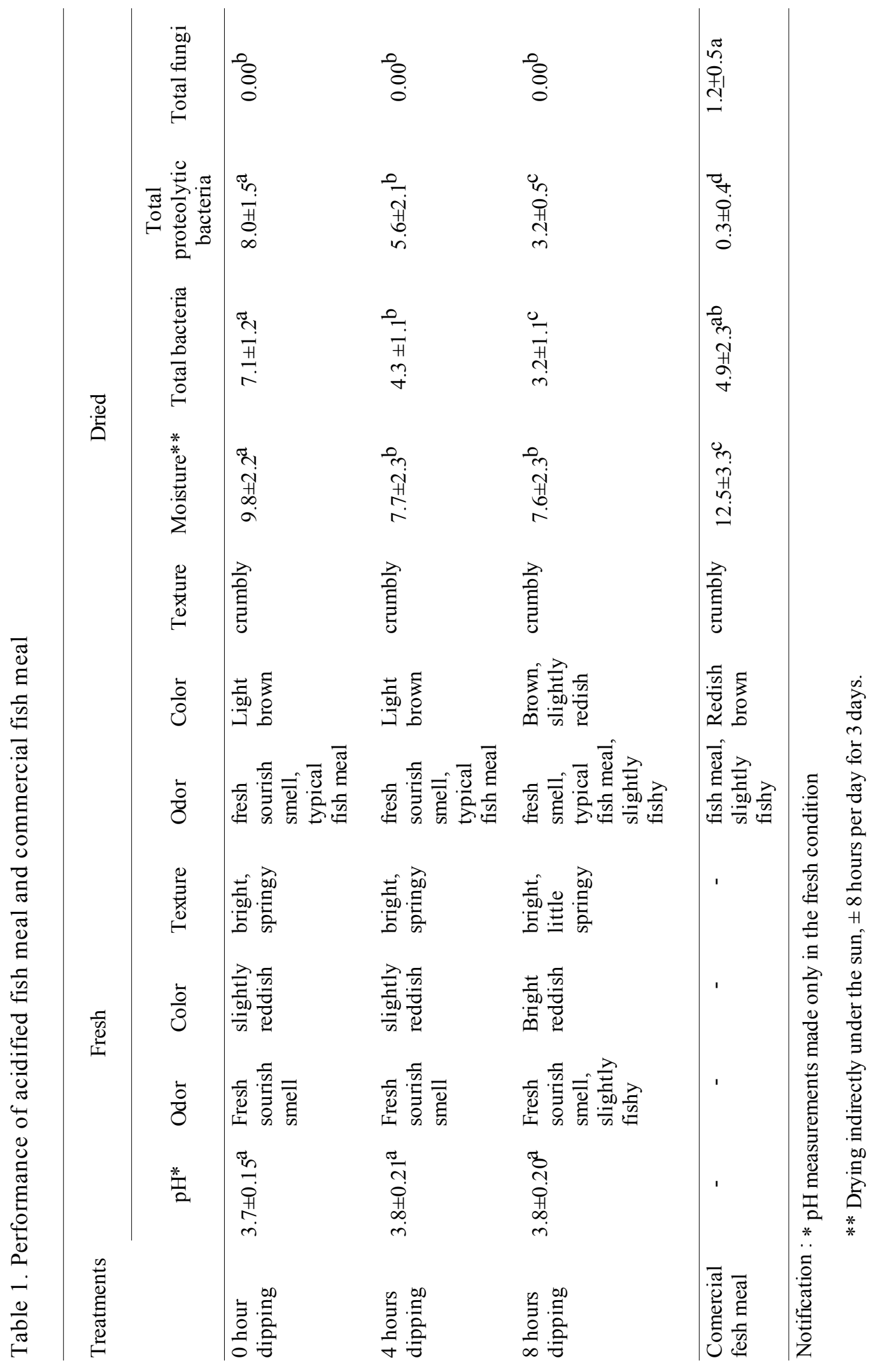


1992). Lactic acid bacteria were a group of bacterial species having ability to form lactic acid as the results of carbohydrate metabolism and able to grow in low range of $\mathrm{pH}$ (Rahayu, 1989). Acid production of lactic acid bacteria is running quickly, so that the growth of other unwanted microorganisms can be obstructed. However, bacterial acid groups are also proteolytic optionally (Butt, 1999), so it remains possible to develop in acid conditions. According to Desrosier (1988) and Hudaya and Daradjat, (1980), the effectiveness of organic acid for the preservation influenced the amount and type of organic acid used. Meanwhile, Feresu and Muzondo (1990) noted the ability lactic acid bacteria to pressure the growth of E.coli bacteria in the non-pasteured milk to be equivalent to the results pasteurization. Evidenced in the case of soaking in this research, groups of lactic acid bacteria and organic acid solution in the Sauerkraut extract provide enough of acid to maintain the atmosphere, so it does not indicate the existence of other microbes as shown in the comparison of the actual number of bacteria and proteolytic bacteria.

Unlike the bacteria, clearly effect of treatment was found to the number of fungi $(p<0.05)$. The fungi were almost not found in the fish meal processed, but it was found in the commercial product. Buckle et al. (1987) described that the optimum growth of microorganisms are allowed several factors, those were temperature of the environment, $\mathrm{pH}$, nutrition supply, activity of water, and availability of oxygen. Therefore, growth of microorganism could be controlled by enhancing growth of supporting factors. Feed preservation can be done by physical, biological and chemically treatments, like drying, increasing osmotic pressure, heating, pickling, irradiating, allowing anti-oxidant and freezing (Woolford, 1992). Introducing organic acid and decreasing $\mathrm{pH}$ were constitutes effective method for foods preservation. Utilizing organic acid to control bacteria and fungi provide good impact on animal that consume acidified feedstuffs (Seerly, 1993 and Johnson, 1992). Cahyadi (2006) and Daryatmo (2000) noted that organic acids were able to control bacteria and fungi in processed food products. This research proved that organic acid in the solvent extracts of Sauerkraut provide acid condition during the process of soaking and the moisture content bellow $10 \%$, so it did not enable the growth of fungi. The fungi in the commercial fish meal could be considered as contaminant materials that contaminate it during processing and or handling.

\section{CONCLUSION}

It is concluded that actual number of total bacteria, fungi and proteolytic bacteria of fish meal influenced by time dipping. Dipping in the Sauerkraut-extract effectively suppressed the number of total bacteria, fungi and proteolytic bacteria of fishmeal, and performed better physical performances than that of commercial product.

\section{ACKNOWLEDGMENTS}

We wish to thank you to Prof.C.Imam Sutrisno, Sri Sumarsih, C.S. Utama and Ciciek Darmawati for warm discussion during the laboratory analyses and preparation of this manuscript.

\section{REFFERECES}

Afrianto, E. dan E. Liviawaty. 2005. Pengawetan dan Pengolahan Ikan. Cetakan Pertama. Penerbit Kanisius, Yogyakarta

Amin, W. dan T. Leksono. 2001. Analisis pertumbuhan mikroba ikan jambal siam (Pangasius sutchi) asap yang telah diawetkan secara ensiling. J. Natur Indonesia. 14 (1):1-9

BPS Semarang. 2005. Kabupaten Semarang dalam Angka 2005. Biro Pusat Statistik Kerjasama dengan Pemerintah Kabupaten Semarang, Ungaran

Buckle, K. A., R. A. Edward, G. H. Fleet dan M. Wootton. 1987. Ilmu Pangan. UI-Press, Jakarta. (Translated by Purnomo $\mathrm{H}$ and Adiono)

Butt, H. 1999. Exploring Management Protocols for Chronic Fatique Syndrome: A Case for Pro And Prebiotics. Probiotica. 8:2-6

Cahyadi, W. 2006. Kajian Analisis Bahan Tambahan Pangan. Edisi Pertama. Bumi Aksara, Jakarta.

Carey, C. M., M.Kostrzynska, S. Ojha and S. Thompson. 2008. The effect of probiotics and organic acids on Shiga-toxin 2 gene expression in enterohemorrhagic Escherichia coli O157:H7. J. Microb. Methods. 73 (2):125-132.

Christine M., C.Vergès, E. Maguin, MY. Mistou, P. Anglade and JF.Chich. 2002. Lactic acid 
bacteria and proteomics: current knowledge and perspectives. J.of Chromatography B: Analytical Technologies in the Biomedical and Life Sciences, 771(1-2) :329-342.

Daryatmo, J. 2000. Manajemen Penyimpanan Pakan. Penerbit Transito, Bandung.

Daulay, D dan A. Rahman. 1992. Teknologi Fermentasi Sayuran dan Buah-Buahan. Pusat Antar Universitas Pangan dan Gizi IPB, Bogor.

Desrosier, N. W. 1988. Teknologi Pengawetan Pangan. Penerbit Universitas Indonesia, Jakarta. (Translated by Muljohardjo)

Feresu, S. and M. I. Muzondo. 1990. Identification of some lactic acid bacteria from two Zimbabwean fermented milk products. World J. of Microb and Biotech. 6:178-186.

Johnson, J.1992. Role For Acidfiers And Enymes In Assuring Performans And Health Of Pigs Post Weaning. In: Improving Nutrient Utilization While Reducing Pollution: A New Dimension Through Biotechnology. APLT-Altech. P 81-92

Hudaya, S dan S. Daradjat, 1980. Dasar-dasar Pengawetan I. Departemen Pendidikan dan Kebudayaan, Jakarta.

Ilyas, S., F.Cholik, R.Afrifudin, N.Naamin, S.T.Soekarto, Siswoputranto, Soedjarwo dan K.C.Chong. 1988. Prospek Pengusahaan Tepung Ikan Indonesia. Proceeding Lokakarya Tepung Ikan. Pusat Penelitian dan Pengembangan Perikanan,Balitbang Pertanian, Deptan. Jakarta. P 41-56

Kompiang, I. P. Dan S. Ilyas. 1983. Pembuatan silase ikan dengan penggunaan asam formiat. J. Penelitian Teknologi Hasil Perikanan. 60 : 12-20

Pouwels, P. H., R.J. Leer, M. Shaw, MJH BakGlashouwer, F.D. Tielen, E. Smit, B. Martinez, J.Jore and P. L. Conway. 1998.
Lactic acid bacteria as antigen delivery vehicles for oral immunization purposes. Intl. J. Food Microb. 4 (2):155-167

Rahayu, K. 1989. Mikrobiologi Pangan. Pusat Antar Universitas Pangan dan Gizi. Universitas Gadjah Mada, Yogyakarta.

Rahmat, A. dan J. Trimurti . 1993. Silase Ikan:Kumpulan Hasil-hasil Penelitian Pasca Panen Perikanan. Pusat Penelitian dan Pengembangan Perikanan. Jakarta. P 8-10.

Rehman, H, W.Vahjen, A.K.Parsini, A.Ijaz and J.Zentek. 2009. Influence of fermentable carbohydrates on the intestinal bacteria and enteropathogens in broilers. World Poult.Sci. J. 65(1):75-90

SAS Institute. 1982. SAS User Guide: Statistics, pp: 139-200.

Seerly, R.W. 1993. The important acidification in monogastric nutrition. In: Biotechnology the use of sciencetifically proven natural products to increase practical value. APLTAltech. P:123-132

Sulistiyanto, B., C. S.Utama and K. Nugroho, 2009. Effect of different techniques of acidifications by sauerkraut extracts to physical performance of acidified fish meal. J. Kesehatan. 2(1): 14-18.

Utama C. S and A. Mulyanto. 2009. Potensi limbah pasar sayur menjadi starter fermentasi. J. Kesehatan. 2(1): 6-13

Volk, W. A dan M. F. Wheeler. 1993. Mikrobiologi Dasar. Jilid 2. Edisi Kelima. Erlangga, Jakarta.

Woolford, M. K. 1992. Feed Preservation Methods. In: improving nutrient utilization while reducing pollution: A New demension through biotechnology. APLT-Altech. P: $173-188$.

Yunizal. 1986. Teknologi Pengawetan Ikan Dengan Proses Silase. Sub-Balai Penelitian Laut Slipi, Jakarta. 